\title{
MENINGKATKAN \\ KUALITAS BAHASA INDONESIA \\ MELALUI BAHASA INDONESIA HUKUM ILMIAH
}

\author{
Dheni Harmaen
}

Dosen Fakultas IImu Seni dan Sastra Universitas Pasundan Bandung, Jl. Dr. Setiabudi No. 193 Bandung, Telp. (022) 2002984 , Fax. (022) 2001984, HP. 085221242846 Email: dheniharmaen@yahoo.co.id

\begin{abstract}
ABSTRAK
Bahasa hukum bukanlah bahasa yang berdiri sendiri, melainkan murupakan bahasa Indonesia yang khusus diterapkan untuk bidang hukum. Bahasa hukum tidak boleh meninggalkan kaidah-kaidah yang berlaku dalam bahasa Indonesia, baik mengenai susunan kalimat, asal usul kata, arti kata maupun aturan-aturan lain yang berlaku dalam bahasa Indonesia. Pola pikir yang konsepsional adalah suatu teori praktis dalam membuat suatu karangan ilmiah, tentunya bahasa hukum juga mempunyai ciri khas sesuai dengan karakter yang terdapat dalam ilmu hukum itu tersendiri, dalam beberapa hal penggunaan bahasa hukum berbeda dengan bahasa Indonesi pada umumnya, namun perbedaan tersebut hanya bersifat kasuistis, termasuk pemakaian bahasa dalam keilmuan lainnya, hal ini dapat dilihat dari penggunaan kata yang hanya berlaku untuk keilmuan tertentu saja yang biasa kita sebut bahasa fungsional atau bahasa profesi.Ragam bahasa Indonesia hukum dilihat dari segi linguistik adalah meta bahasa yaitu merupakan ragam hasil kajian atau produk pemikiran manusia yang tidak terbatas kepada satu bahasa saja, tetapi juga melibatkan keilmuan lain. Dipandang dari bahasa hukum maka bahasa Indonesia hukum adalah sarana utama untuk menjalankan profesinya, sehingga bahasa profesi mempunyai ciri yang berbeda dari ragam bahasa umum.
\end{abstract}

Kata kunci: Bahasa, Hukum, Fungsi, dan Profesi. 


\begin{abstract}
Legal language is not the language that stands alone, but rather a special Indonesian which applied to the field of law. Statutory language should not leave the rules that apply in Indonesian, both on sentence structure, word origin, meaning and other rules applicable in Indonesian. Conceptual mindset is a practical theory in making a scientific essay, of course, the legal language also have characteristics in accordance with the characters contained in the legal science itself, in some instances the use of legal language different from the general Indonesian language, but the difference is merely casuistry, including the use of language in other scientific, it can be seen from the use of the word which is only valid for a certain science that we call functional language or profession languages. The diversity of Indonesian law in terms of linguistics is a meta language that is diverse results of the study or product of human thought which is not limited to just one language, but also involves other scientific. In light of the language of law, Indonesian law is the primary means for carrying out their profession, so the language professions have different features from a variety of common language.
\end{abstract}

Keywords: Language, Law, Function, and Profession. 


\section{PENDAHULUAN}

Bahasa memegang peranan penting dalam kehidupan manusia, karena tanpa bahasa semua komunikasi tidak akan pernah terjadi. Oleh karena itu untuk mencapai terstruktur dan sistematik, dipelajarilah bahasa. Sejak seorang bayi lahir dari rahim ibunya, bahasa sudah diajarkan. Mula-mula bahasa diajarkan tanpa struktur dan sistematis, lalu setelah anak mulai bersekolah bahasa diajarkan secara struktural. Dengan demikian, seseorang dapat membedakan antara bahasa yang dipakai dalam situasi formal dan non-formal. Memang tampaknya mempelajari bahasa terasa membosankan, sehingga seringkali diabaikan. Hal ini disebabkan tampa mempelajari bahasa pun mereka sudah terbiasa menggunakan bahasa Indonesia semenjak mereka belajar berbicara. Alasan ini membuat mereka tidak perlu lagi mempelajari bahasa.

Penelitian membuktikan bahwa sementara kaum cendikiawan Indonesia sampai saat ini masih belum fasih berbahasa Indonesia secara terstruktur. Padahal jika kita lihat bahasa Indonesia yang menggunakan Ejaan Yang Disempurnakan (EYD) sudah empat puluh tiga tahun diresmikan dan sudah terlihat perkembangannya tetapi keajegannya kurang diperhatikan oleh orang Indonesia sendiri. Ini perlu segera dibenahi karena tiap tahun orang asing yang belajar bahasa Indonesia ( di Fakultas Sastra) terus berdatangan. 
Jangan sampai pada akhirnya orang Indonesia belajar bahasa Indonesia di negara asing.

Hal ini penulis paparkan karena pengalaman menunjukkan bahwa hukum Indonesia sampai saat ini masih terlihat ciri bahasa Belandanya yang begitu melekat. Sejarah membuktikan bahwa bahasa Indonesia terutama bahasa undang-undang berasal dari produk orang Belanda (hasil jajahan bangsa Belanda). Pakar hukum Indonesia pun banyak belajar ke negeri Belanda kerena hukum Indonesia mengacu pada hukum Belanda. Para pakar hukum Indonesia menerjemahkan langsung pengetahuan dari bahasa Belanda ke dalam bahasa Indonesia tanpa mengindahkan struktur bahasa Indonesia itu sendiri. Ini dapat dilihat dari kebenaranya kata di mana, yang mana, dari mana, hal mana. Sebenarnya hal tersebut tidak perlu terjadi karena kata di mana, yang mana, dari mana, hal mana itu merupakan kata tanya, di dalam kalimat berita atau kalimat pernyataan dalam bahasa Indonesia tidak ada tempat untuk menggunakan kata tanya.

Kesalahkaprahan seperti itu kemudian diikuti oleh pakar hukum generasi selanjutnya. Akan tetapi, setelah beberapa kali kongres bahasa Indonesia diselenggarakan, bahasa hukum Indonesia sudah banyak kemajuan. Bertolak dari semua itu, maka seringlah diadakan seminar tentang bahasa hukum. Hal ini membuat para pakar hukum lebih berhati-hati menggunakan bahasa Indonesia dalam tulisannya. Ini dapat kita lihat dari produk undang- 
undang yang disyahkan dan dipakai dewasa ini sudah banyak perbaikan di sana sini. Perkembangan bahasa tersebut sangat mengembirakan bangsa Indonesia, khususnya para pakar hukum, karena produk hukum Indonesia sudah merupakan hasil pemikiran bangsa Indonesia.

Sehubungan dengan hal tersebut, bagi seseorang yang mempelajari ilmu hukum, bahasa itu memerlukan perhatian yang lebih. Ini tidak terlepas dari hukum itu sendiri. Hukum merupakan produk pemikiran, pikiran baru bisa stabil apabila ditunjang oleh bahasa yang baik. Hukum dapat berbicara dan didengar oleh masyarakat melalui bahasa, tentu saja bahasa yang digunakannya pun haruslah bahasa formal. Di sini baru jelas apabila seseorang mempelajari hukum harus juga belajar bahasa. Jika seorang ahli hukum menguasai perbendaharaan kata yang lebih banyak, maka sudah dapat dipastikan bahwa dia akan mahir dalam mempraktikkan ilmu hukum yang dipelajarinya.

Bahasa Indonesia hukum adalah salah satu ragam bahasa Indonesia yang digunakan sebagai alat komunikasi dalam bidang hukum. Bahasa Indonesia hukum digunakan oleh orang-orang berkecimpung dalam bidang hukum atau pendalami ilmu hukum. Ragam bahasa hukum, seperti juga ragam-ragam bahasa lainnya, merupakan bahasa ilmiah, jadi harus memperhatikan ciri-ciri struktur atau kaidah-kaidah bahasa Indonesia baku. Oleh karena itu, bahasa hukum tidak mengutamakan gaya bahasa, tetapi 
mengutamakan kepastian bahasa. Tentu saja, harus dipastikan bahwa bahasa hukum itu tidak boleh bersifat ambigu (mengandung lebih dari dua

pengertian). Jika terjadi keambiguan penggunaan bahasa, maka terjadi ketidakpastian hukum.

Kita semua mengetahui bahwa bahasa Indonesia itu dibagi ke dalam dua bentuk, yaitu bahasa Indonesia baku dan bahasa Indonesia tidak baku. Bahasa baku digunakan dalam komunikasi resmi seperti pada pidato kenegaraan, naskah perundang-undangan, pembuatan skripsi, makalah, seminar, ujian sidang, rambu-rambu lalu lintas dan sebagainya. Sedangkan yang tidak baku digunakan dalam situasi yang tidak resmi, misalnya dalam berkelakar, berbicara dengan teman, tawar-menawar di pasar misalnya. Ini semua tercakup dalam struktur bahasa Indonesia.

Sebagai dasar pemikiran kita tentang pentingnya sarana bahasa Indonesia hukum telah dibahas dan dikaji berulang kali oleh pakar-pakar bahasa serta penegak hukum, diantaranya sebagai berikut :

1. Pada tahun 1972, Badan Pembinaan Hukum Nasional Departemen Kehakiman (BPHNDK) telah merealisasikan anjuran presiden dengan mengeluarkan karya ilmiah tentang "Bahasa Indonesia Hukum".

2. Pada tahun 1974, di kota Medan, anggota simposium tentang "Bahasa dan Hukum" mengkaji bahasa hukum yang digunakan pada saat masih 
banyak kekurangan dalam hal semantik, bentuk kata, dan komposisi kalimat.

3. Hasil dari seminar "Hukum Nasional ke III" di Surabaya pada tahun 1974, telah menerbitkan karya ilmiah tentang "Pembinaan Bahasa Hukum".

4. Perevisian dan pemodifikasian buku-buku yang ditulis oleh pakarpakar bahasa dan hukum telah banyak diterbitkan, diantaranya oleh Prof.Dr. Mahadi, SH., Drs. Sabarudin Ahmad, Dr. Soelaeman B. Adiwidjaja, Dip.Drs.Ed.SH. dan sebagainya.

Ini semua menunjukan bahwa Bahasa Indonesia Hukum memiliki peranan penting dalam bidang hukum. Berdasarkan latar belakang sebagaimana diuraikan di atas, maka dapat diidentifikasi beberapa permasalahan, antara lain : Bagaimana Hubungan Bahasa dengan IImu Hukum; Bagaimana Bahasa yang Esensial Dalam IImu Hukum; Apakah Fungsi Bahasa Indonesia Hukum.

\section{PEMBAHASAN}

A. Hubungan Bahasa dengan Ilmu Hukum

Bahasa hukum tersusun dari simbol-simbol yang mempunyai arti khusus. Keistimewaannya dalam bahasa hukum ialah orang selalu merasa tidak puas terhadap makna yang terkandung dalam suatu 
istilah hukum. Sehingga orang akan terus menerus mencari makna yang paling tepat. Untuk mencari makna tersebut yang digunakan dalam bahasa hukum haruslah terdiri dari simbol-simbol yang bisa dipahami oleh si penerima atau pendengar.

Dengan demikian komunikasi hukum yang didasarkan pada bahasa hukum perlu dipahami sebaik mungkin, agar pihak-pihak yang berkomunikasi saling memahami dan mengerti apa yang mereka bicarakan. Dalam pembicaraan sehari-hari khususnya yang digunakan oleh praktisi hukum, sering kita mendengan berbagai istilah yang mereka ucapkan merupakan kata yang baru dan asing di telinga kita, misalnya ;

1. Kata cekal, mengandung pengertian untuk menyatakan seseorang yang tidak dibolehkan masuk atau keluar dari negara Indonesia.

2. Kata inkonstitusional, mengandung pengertian untuk menyatakan setiap kegiatan masyararakat baik perorangan ataupun kelompok yang tidak sesuai atau bertentangan dengan aturan-aturan yang berlaku.

Di samping itu banyak kata-kata atau istilah lain yang hampir setiap saat digunakan seperti kata : relevansi, kedaluwarsa, dasawarsa, dan sebagainya. Kata-kata tersebut sebenarnya merupakan ucapan yang lazim digunakan, bahkan sebagaian besar diantaranya sudah 
dibakukan menjadi bahasa Indonesia, akan tetapi karena pemahaman kita masih sangat kurang, tidak menutup kemungkinan bahwa kita akan keliru menafsirkan ucapan-ucapan tersebut.

Secara garis besar dasar-dasar pokok dari bahasa hukum dapat dibagi menjadi tiga kelompok :

1. Bahasa hukum yang bersumber pada aturan-aturan hukum yang dibuat oleh negara.

2. Bahasa hukum yang bersumber pada hukum yang berlaku di tengah-tengah masyarakat, Bahasa hukum seperti ini kita temui dalam hukum adat yang berlaku dan tidak bertentangan dengan hukum negara.

3. Bahasa hukum yang bersumber dari para ahli hukum, kelompokkelompok profesi hukum.

Masing-masing dari ketiga kelompok di atas mempunyai ciri-ciri tersendiri dalam pemakaian sehari-hari. Bahasa hukum yang bersumber pada aturan-aturan hukum yang dibuat oleh negara dapat kita lihat mempunyai ciri tertentu yang lebih bersifat pengaturan hak dan kewajiban. Contoh: seperti aturan tentang panintentir yaitu aturan tentang perlindungan anak, konveksi, kontraktual, dan sebagainya. Sedangkan dalam bahasa hukum yang bersumber pada hukum yang berlaku di tengah-tengah masyarakat, dapat kita lihat seperti kata-kata 
atau istilah-istilah: gono-gini, subak, semenda, jujur, dan sebagainya. Selanjutnya yang bersumber dari para ahli hukum atau kelompok profesi hukum, yang mencerminkan bahasa ilmiah hukum umpamanya: kontributif, distributif, demokratisasi, politisasi, liberalisasi, deregulasi, debirokratisasi, dan lain-lain.

Di sini baru jelas bahwa orang yang mempelajari ilmu hukum harus juga belajar bahasa. Jika seorang ahli hukum menguasai pembendaharaan kata yang lebih banyak, maka sudah dapat dipastikan bahwa dia akan mahir dalam mempraktikan ilmu hukum yang dipelajarinya.

Hubungan bahasa dengan hukum dapat kita rumuskan sebagai berikut :

1. Hukum merupakan produk pemikiran, pikiran bisa luwes dan stabil apabila ditunjang oleh bahasa yang baik dan benar.

2. Gagasan atau ide-ide seseorang dalam ilmu hukum dapat diungkapkan kepada si-penerima melalui bahasa.

3. Hukum dapat berbicara dan didengar oleh masyarakat melalui bahasa.

4. Hukum tidak mengutamakan gaya bahasa tetapi hukum lebih memerlukan kepastian bahasa.

5. Hukum memerlukan bahasa lahir bukan bahasa bathin. 
6. Berbahasa dalam hukum mengandung akibat hukum, jadi dalam berbahasa harus benar-benar dipertanggungjawabkan hukumnya.

Hukum merupakan rangkaian (himpunan) petunjuk-petunjuk tentang perintah-perintah dan larangan-larangan yang mengatur tata tertib kehidupan manusia di masyarakat, yang harus ditaati oleh setiap anggota masyarakatnya, oleh karena itu pelanggaran terhadap petunjuk hidup tersebut dapat menimbulkan tindakan dari fihak pemerintah atau dari fihak penyelenggara aturan. Dengan demikian untuk menumbuhkan dan membina serta memupuk kesadaran hukum di masyarakat harus menggunakan sarana bahasa Indonesia, guna mengungkapkan petunjuk dalam aturan-aturan tersebut.

Bahasa sebagai bahasa komunikasi, sama tuanya dengan usia manusia, artinya bahasa itu ada sejak manusia itu mampu berbicara. Walaupun usia bahasa sudah sedemikian tua, namun sampai saat ini belum ada satu catatan atau literatur yang membahas tentang waktu dimulainya pemakaian bahasa sampai berkembang menjadi banyak seperti yang dipakai sekarang ini. Suatu hal yang pasti adalah bahwa kita tidak pernah membayangkan apabila hidup kita tampa bahasa, juga kita tidak pernah membayangkan bagaimana jika di dunia ini semua mahluk dapat berbicara seperti manusia. Jadi kelebihan manusia 
dibandingkan dengan makhluk lainnya bukan hanya terletak pada kelebihan akalnya saja melainkan juga kelebihan dalam kemampuan berbahasanya. Tampa kemampuan berbahasa, manusia tidak bisa mengembangkan kebudayaannya, sebab tampa kemampuan berbahasa hilang pula untuk meneruskan nilai-nilai budaya dari generasi yang satu kepada generasi selanjutnya. Disamping itu tampa kemampuan berbahasa tersebut manusia tidak dapat melakukan berpikir secara sistematis dan teratur.

Tidak dapat dibantah pula bahwa ungkapan pikiran tidak dapat dilakukan tampa bahasa. Sekaitan dengan pemahaman hukum, perlu pula dipelajari bahasa Hukum seperti halnya bahasa Indonesia. Hal tersebut dibahas pula dalam Simposium Bahasa Hukum pada tahun 1974 yang diselenggarakan oleh Badan Pembinaan Hukum Nasional (BPHN) di Medan, telah rumuskan bahwa bahasa Indonesia Hukum adalah bahasa Indonesia yang digunakan dalam bidang hukum, dan bahasa Hukum adalah bahasa Indonesia yang memiliki sifat khas yang digunakan di dunia hukum Indonesia.

Bahasa hukum tersusun dari simbol-simbol (lambing bunyi) yang mempunyai arti khusus. Keistimewaanya dalam bahasa hukum adalah orang selalu merasa tidak puas terhadap makna yang dikandung dalam suatu istilah hukum, sehingga orang selalu mencari terus 
menerus makna yang paling tepat. Untuk mencari makna tersebut yang digunakan dalam bahasa Hukum haruslah terdiri dari simbolsimbol yang dapat dipahami oleh sipenerima atau sipendengar. Dengan demikian komunikasi hukum yang didasarkan kepada bahasa Hukum harus dipahami sebaik mungkin, agar pihak - pihak yang berkomunikasi saling memahami dan mengerti apa yang mereka bicarakan. Dalam pembicaraan sehari-hari baik di tingkat elite politik maupun para praktisi hukum sering kita mendengar berbagai istilah yang mereka ucapkan merupakan kata yang baru atau kata-kata yang masih asing kedengarannya, antara lain, untuk menyatakan seseorang tidak boleh masuk atau keluar dari Negara Indonesia mereka menggunakan istilah cekal yang merupakan akronim dari cegah dan tangkal. Demikian pula mengenai berbagai kegiatan di masyarakat, baik yang dilakukan oleh perorangan atau sekelompok orang, mereka menggunakan istilah inkonstitusional, relevansi, kedaluwarsa, dasawarsa dan sebagainya. Kata-kata tersebut merupakan kata-kata yang sudah lazim digunakan, bahkan sebagaian diantaranya sudah dibakukan menjadi bahasa Indonesia, akan tetapi pemahaman terhadap bahasa Hukum masih sangat kurang, maka tidak tertutup kemungkinan kita akan keliru menafsirkan ucapan-ucapan tersebut. 
Untuk memahami Bahasa Hukum yang menjadi pangkal tolak pemikiran adalah permasalahan yang menyangkut hukum itu sendiri. Untuk itu kita harus berorientasi pada fenomena-fenomena hukum yang ada di tengah-tengah masyarakat. Baik para sarjana hukum maupun mahasiswa hukum haruslah merupakan orang yang menguasai dan memahami sepenuhnya bahasa yang dipergunakan untuk merumuskan aturan - aturan hukum, hal tersebut merupakan suatu persyaratan mutlak, karena seorang sarjana hukum harus mampu manyatakan atau mengungkapkan dengan baik pikiran-pikirannya yang berhubungan dengan hukum atau tentang hak dan kewajiban, pikiranpikiran tersebut sudah barang tentu diungkapkan dalam Bahasa Hukum. Bertitik tolak dari pandangan seperti ini, dapat dikatakan bahawa hukum itu tidak lain dari bahasa yang diterapkan atau diungkapkan melalui simbol-simbol yang bertujuan untuk mengatur dan menertibkan masyarakat.

\section{B. Bahasa yang Esensial Dalam IImu Hukum}

Aspek kebahasaan terdiri atau empat kemahiran, yaitu dalam berbicara, mendengar, menulis dan menyimak. Ditambahkan pula bahwa kemahiran berbahasa dapat mengubah kepribadian seseorang dalam kehidupannya. Kemahiran berbahasa sangat diperlukan oleh orang-orang yang berkecimpung dalam bidang (profesi) ilmu hukum. 
Betapa pentingnya peranan bahasa Indonesia untuk kepentingan ilmu hukum, hal ini dapat dilihat dari produk-produk hukum yang ada sekarang dan bahkan yang akan datang, juga disebabkan hukum merupakan salah satu dari produk pemikiran. Proses pemikiran baru akan mantap apabila ditunjang oleh struktur bahasa hukum. Di bawah ini terdapat beberapa bahasa yang esensial untuk menunjang proses berpikir adalah sebagai berikut :

1. Melukiskan peristiwa yang terjadi secara kronologis

Dalam bidang hukum kita sering berhadapan dengan masalahmasalah yang berhubungan dengan waktu. Peristiwa-peristiwa yang terjadi berdasarkan waktu hendaknya diurutkan secara kronologis. Kronologis sangat penting dalam pembuatan Berita Acara Pemeriksaan (BAP). Kronologis juga mempunyai nilai praktis yaitu dapat melukiskan kasus-kasus yang terdapat dalam bidang hukum secara terstruktur dan sistematis. Oleh karena itu, perlu diperhatikan dalam membuat kalimat secara kronologis kita harus memperhatikan polapola kalimat dalam bahasa Indonesia. Pada kalimat tersebut harus terpenuhinya unsur subjek, predikat dan objek (keterangan). Jika salah satu unsur tersebut tidak terpenuhi, maka kalimat-kalimat yang dibuat tidak akan sempurna dan rancu.

Contoh kalimat yang mempunyai ciri kronologis : 
1) Deklarasi Djuanda diumumkan pada tanggal 13 Desember 1957

2) Sumpah Pemuda diadakan pada tanggal 28 Oktober 1928.

3) Proklamasi Kemerdekaan diumumkan sebelum UUD 1945 disahkan.

Dalam kronologis digunakan kata-kata yang mendukung peristiwa yang terjadi, yaitu adanya keterangan waktu, digunakan pula kata yang menyatakan waktu, seperti kata sesudah, sebelum, sekarang, pada saat ini, besok, dan lain-lain.

\section{Melukiskan Tata Letak}

Selain peristiwa yang dinyatakan menurut urutan waktu secara kronologis, dalam bidang hukum ini sering digunakan kalimat-kalimat yang memerlukan kejelian dalam mengungkapkan tata letak. Pada prinsipnya melukiskan tata letak hampir sama dengan melukiskan urutan waktu, hanya dalam tata letak harus diungkapkan secara jelas, cermat dan tepat, apabila kita menemui suatu kasus (tindak pidana atau perdata) tertentu, penyelidikannya akan benar-benar tergambarkan. Biasanya lukisan tata letak ini diperlukan oleh para penyidik dalam membuat Berita Acara Pememeriksaan (BAP).

Contoh kalimat yang menyatakan lukisan tata letak:

1) Barang curian itu ada di bawah tempat tidur pembantu, disimpan di dalam kopor yang sudah lusuh. 
2) Dia duduk di depan di sebelah kiri sopir.

3) Papan tulis itu berada di dalam kelas.

4) Kantor tempat ia bekerja tidak jauh dari rumahnya.

3. Melukiskan Hal yang Umum dan Khusus

Dalam bidang hukum ada suatu peristiwa yang harus dinyatakan secara umum kemudian dirinci secara spesifik. Melukiskan hal yang umum dan yang khusus itu sering terjadi dalam kasus-kasus yang berkembang di masyarakat. Jika kita perhatikan realisasi hasil penyelidikan dan penyidikan di masyarakat, maka contoh berikut dapat melukiskan hal yang umum dan yang khusus. Misalnya, Segala warga Negara sama di dalam hukum dan wajib menjunjung tinggi hukum. (UUD 1945: pasal 27)

Kata segala menunjukkan tidak ada kekecualian (WNI dan WNA) mempunya kedudukan yang sama dalam hukum. Jadi, penegak hukum bukan hanya alat negara seperti $A B R I$ tetapi seluruh warga negara termasuk di dalamnya orang asing yang tinggal di Indonesia. Kita harus ingat bahwa jika suatu undang-undang atau peraturanperaturan sudah disahkan, semua warga negara yang bersangkutan harus mengetahuinya. Ada fiksi hukum yang isinya menyatakan sekali undang-undang disahkan, semua warga negara harus tahu. 
4. Klarifikasi atau Mengelompokkan.

Perlunya seorang ahli hukum menyatakan gagasan dengan cara pengelompokkan adalah agar mereka dapat membuat peraturan dengan baik dan benar. Klasifikasi atau pengelompokan selain diperlukan untuk membuat $B A P$, juga untuk pembuatan rancangan undang-undang menjadi undang-undang. Kecermatan memilih kata yang tepat diperlukan di sini, karena jika memilih katanya tidak tepat akan membuat isi undang-undang atau peraturan tidak akurat.

Di sini kita harus dapat membedakan antara ragam bahasa hukum dengan ragam bahasa lainnya, misalnya ragam bahasa politik. Hukum dasarnya fakta, sedangkan politik lebih sering menggunakan retorika (kalimat pertanyaan yang tidak memerlukan jawaban). Jika ditelusuri secara etimologi fakta berasal dari fact (fasio), artinya:

(1) Sesuatu yang sudah terjadi dan

(2) Sesuatu yang telah diperbuat. Hukum adalah gagasan politik tetapi sekali politik membuat gagasan, politik harus tunduk pada hukum.

Contoh:

Presiden mengatakan bahwa segala sesuatu harus tunduk pada UUD. Jika bahasa hukum mementingkan fakta, bahasa politik mementingkan retorika, maka lain juga dengan bahasa Sastra. Bagi 
sastrawan, bahasa itu sangat luas cakupannya sehingga sifatnya juga subjektif. Sastrawan berbahasa sebebas-bebasnya, bahkan kadangkadang tanpa mementingkan fakta, untuk mengepresikan daya imajinasinya. Dalam hukum tentu saja hal tersebut sama sekali tidak boleh digunakan karena jika tidak berdasarkan fakta, maka kepastian hukum tidak akan tercapai. Hukum itu bukan khayalan, seperti karya sastra, maka bahasa yang digunakan haruslah bahasa ilmiah.

Bahasa hukum bersifat resmi, maka untuk membuat kepastian hukum, bahasa hukum itu sering kelihatan kaku. Kekakuan bahasa tersebut dapat kita lihat dalam naskah perundang-undangan. Akan tetapi perlu diingat, walaupun kelihatan kaku, bahasa hukum (khususnya bahasa perundang-undangan) harus tetap taat asas terhadap kaidah bahasa Indonesia yang berlaku.

Kata-kata yang mendukung proses pembuatan kalimat pengelompokan adalah mengelompokkan, diklarifikasikan, termasuk, digolongkan, antara lain, terdiri atas, seperti, dan lain-lain. Dapat juga kata-kata yang memnunjukkan pada pengelompokan.

Contoh:

(1) Indonesia termasuk lima besar di dunia.

(2) Hukum digolongkan menjadi dua kelompok, yaitu hukum publik dan hukum perdata. 
(3) Indonesia adalah negara nonblok.

(4) Hukum pidana termasuk ke dalam hukum publik.

(5) Intruksi presiden merupakan bagian dari hukum administrasi negara.

(6) Wilayah yuridiksi Indonesia terdiri atas:

Pulau paling barat : Pulau Rondo

Pulau Paling timur : Pulau Irian

Pulau utara $\quad$ : Pulau Miangas

Pulau selatan : Pulau Roti

(7) Orang berbuat berdasarkan fakta, hak, dan kewajiban.

(8) Hukum perdata melindungi hak-hak perorangan

(9) Kota Bandung adalah bagian dari profinsi Jawa Barat

(10) Indonesia telah menjadi anggota Perserikatan Bangsa-Bangsa.

(11) Semua anggota Asean adalah anggota PBB.

Pengelompokan atau klasifikasi berguna untuk memecahkan suatu masalah atau suatu kasus. Dengan membagi msalah ke dalam kelompok-kelompok, maka penyelidikan pun akan terpecahkan secara gampang dan terstruktur. Dalam BAP, pengelompokan digunakan untuk merinci suatu peristiwa yang terjadi pada suatu masalah.

5. Membandingkan dan Membedakan 
Dalam perbandingan, pertama-tama kita hrus melihat persamaannya. Sedangkan dalam melihat perbedaan adalah apa perbedaannya. Seorang ahli hukum hukum harus memiliki wawasan yang luas tentang segala sesuatu yang berhubungan dengan perbandingan dan perbedaan. Kata serupa (tidak sama dengan atau tidak identik) merupakan salah satu contoh dalam perbandingan dan perbedaan, misalnya, ada saudara kembar yang serupa tetapi tingkah lakunya tidak sama. Salah satu dari mereka melanggar hukum, Seorang ahli hukum harus mencari perbedaan yang hakiki dari kedua saudara kembar tersebut. Jika diteliti dengan cermat, maka perbedaannya dari sidik jari dan sidik daun telinga. Setiap orang di dunia ini mempunyai sidik jari yang berbeda satu sama lain. Menurut penelitian selanjutnya, selain sidik jari pun sidik daun telinga setiap orang tidak sama.

Jika terjadi kasus-kasus serupa, maka seoarang ahli hukum akan menyadari bahwa hukum itu merupakan produk pemikiran. Yang dimaksud produk pemikiran yaitu setiap ada gejala yang menyimpang dalam masyarakat, para ahli hukum harus cepat tanggap untuk mengantisipasi penyimpangan tersebut agar penyimpangannya segera dapat diatasi. Misalnya, negara kita telah diakuinya Deklarasi Djuanda menjadi negara terluas ketiga dunia. Oleh karena itu, betapapun kecilnya pulau yang ada di wilayah Indonesia harus tetap dijaga dan 
dilindungi oleh hukum. Semua itu harus diatur oleh ahli hukum. Begitu juga dengan lautan di Indonesia mempunyai luas 2/3 dari luas seluruh kepulauan yang ada di Indonesia. Sejak 16 November 1994, negara adikuasa, Amerika Serikat (AS) sudah menandatangani perjanjian hukum laut sehingga AS akhirnya mengakui keabsahan undang-undang hukum laut Indonesia.

Contoh tersebut, kiranya dapat membuka hati para ahli hukum Indonesia, agar terus membuat gagasan-gagasan yang inovatif dalam bidang hukum, yang bisa menandai identitas negara Indonesia, agar berbeda dengan negara-negara lainnya. Kekuatan sosial politik Indonesia pun akan diperhitungkan oleh negara - negara lain. Dengan demikian negara Indonesia akan selalu disegani. Sumbangan pemikiran seperti itu sangat berharga bagi bangsa Indonesia.

Di bawah ini adalah contoh wacana yang menunjukkan perbandingan dan perbedaan. Dalam wacana ini isinya adalah membandingkan konsultan asing di Singapura. Di sini juga dijelaskan bagaimana perbedaan antara kedua negara tersebut dalam mengatur konsultan hukum asing.

Di Indonesia, peraturan yang mengatur konsultan hukum asing adalah Keputusan menteri Kehakiman Nomor 2 Tahun 1991, tentang Penggunaan Ahli hukum WNA di Indonesia, Peraturan itu dengan 
tegas menyebutkan, jasa hukum yang dimaksud berupa jasa hukum nonlitigas alias tidak boleh berbicara di ruang persidangan.

Konsultasi hukum itu pun merupakan konsultasi tentang hukum di negara asalnya, hukum negara lain yang dikuasainya, atau hukum internasional. Bila sebuah kantor konsultan hukum ingin memperkerjakan ahli hukum asing, ia harus mengurus izin dari Menteri Tenaga Kerja. Menaker sendiri baru memberi izin bila ada persetujuan dari Menteri Kehakima. Bukan itu saja, sang konsultan hukum asing itu juga diwajibkan memberi jasa hukum ke lembaga pendidikan dan instansi pemerintah, minimal 10 jam per bulan.

Karena prosedur itu cukup rumit, pada kenyataannya banyak konsultan hukum asing yang berpraktik terselubung. Biasanya mereka berlindung di balik kantor konsultan hukum yang sudah ada tentu saja nama mereka tidak disebutkan sebagai partner. Atau mereka berkedok di balik perusahaan konsultan perdagangan di Indonesia. Jadi, izin kerjanya datang dari Menteri Perdagangan, bukan dari Menteri Kehakiman.

Bagaimana pula negara lain mengatur konsultan hukum asing? Salah satu negara yang sudah cermat membentuk perangkat hukum tentang soal konsultan hukum asing adalah Singapura. Sebagai kota internasional, negeri pulau ini memang memperbolehkan ahli hukum 
atau sarjana hukum asing berkarya, di sana. Kesempatan itu terbuka untuk siapa saja, baik ahli hukum dari negara yang memiliki sistem hukum seperti Singapura-Anglo Saxon-maupun ahli hukum dari negara yang menganut sistem kontinental seperti Belanda dan Indonesia.

Praktik konsultan hukum asing di Singapura itu diatur dalam Legal Profession Act (Bab 161), khususnya pasal 2. Pada dasarnya, peraturan itu cukup sederhana dan mudah. Selama orang itu sudah terbukti sebagai ahli dalam bidang hukum, ia dapat bekerja di Singapura.

Biasanya, ada dua alasan bagi ahli hukum untuk datang dan bekerja di Singapura. Pertama, mereka memang sengaja mendirikan perusahaan konsultan hukum sendiri atau patungan mendirikan usaha dengan partner dari Singapura. Untuk mendirikan perusahaan jasa hukum itu, yang diperlukan adalah izin dari Registry of Business and Company.

Alasan kedua, mereka datang untuk bekerja di sebuah perusahaan yang berdomisili di Singapura. Perusahaan itu dapat saja perusahaan jasa hukumyang langsung beracara di pengadilan atau melakukan litigasi. Dapat juga, mereka bekerja di perusahaan umum seperti perminyakan, perkapalan, dan pelayaran, yang biasanya juga 
memiliki bagian hukum. Selain berpraktik litigasi, seorang ahli hukum juga dapat melakukan konsultasi nonlitigasi.

Untuk bekerja di sebuah perusahaan jasa hukum di Singapura, syaratnya cukup berat. Pertama, mereka harus Iulusan fakultas hukum yang diakui atau kurikulumnya sama dengan Singapura. Universitas yang diakui umumnya dari Inggris, Australia, Malaysia, dan Selandia baru. Bila bukan berasal dari universitas yang diakui, mereka harus mengikuti ujian Postgraduste Law Course yang diadakan Board of Legal Education. Badan ini beranggotakan wakil pemerintah- Ministry of Law-akademi dari National University of Singapore, dan dari kejaksaan agung.

Syarat itu akan bertambah mulai dari 1 Januari 1997. Seorang yang akan bekerja sebagai ahli hukum di Singapura harus Iulus dan mendapatkan Diploma in Singapore law dari National University of

Singapore. Dengan bekal-bekal itu, pengacara asing dapat melakukan litigasi langsung di persidangan.

Untuk ahli hukum yang bekerja di perudahaan umum, syaratna lebih ringan. Mereka harus sarjana hukum atau ahli hukum dari sebuah negara, bila membuktikan profesionalisme dan pengetahuan atas $U U$ dan hukum negaranya. Mereka dapat saja tingggal di Singapura, tapi 
boleh juga di luar Singapura. Jika ingin tinggal di Singapura, mereka harus mendapat izin dari imigrasi Singapura. Gaji yang mereka peroleh bila berdomisili di Singapura harus lebih dari $\$ \$ 2$ ribu per bulan.

Untuk ahli hukum yang bekerja sebagai konsultan hukumnonlitigasi-syaratnya sama seperti yang diterapkan bagi pekerja asing, dengan keahlian di bidang lain seperti dosen, insinyur, atau dokter. Kontrak kerja sebagai konsultan hukum asing itu diatur oleh UU imigrasi. Selain harus mendapat gaji di atas $S \$ 2$ ribu, juga harus ada sponsor dari perusahaan yang sudah diakui eksistensinya di Singapura. Semua ahli hukum yang bekerja di Singapura disarankan masuk menjadi anggota Law Society of Singapore (persatuan Pengacara Singapura).

Kata-kata yang menjadi ciri dari perbandingan dan perbedaan adalah kata serupa, berbeda, persamaannya, perbedaannya, sama dengan, daripada, dan kata-kata atau frase yang menunjukkan perbandingan dan perbedaan. Hal ini dapat terlihat dalam bentuk kalimatnya.

Contoh:

(1) Indonesia mempunyai wilayah laut lebih luas daripada wilayah daratan.

(2) Manakah yang harus lebih berkuasa hukum atau kekuasaan 
(3) Indonesia adalah salah satu negara berkembang, tetapi Jerman adalah salah satu negara maju.

(4) Negara berkembang berbeda dari negara yang sudah maju.

(5) Hukum publik serupa dengan hukum perdata.

(6) Indonesia serupa dengan Jepang, Kedua negara itu merupakan negara kepulauan, hanya, kepulauan Indonesia yang lebih luas.

6. Mengelompokkan yang Diperluas

Seorang ahli hukum harus belajar secara konsepsional:Iatihan meneliti;menjadi penyusun yang baik atau organisator yang baik. Dengan kemampuan seperti itu, seoarang ahli hukum akan siap menghadapi kasus-kasus yang terjadi di masyarakat. Seperti kita ketahui bersama, bahwa hukum itu berkembang sesuai dengan perkembangan zaman. Jadi, jelas bahwa kasus-kasus hukum pun akan berkembang. Pemikiran yang konsepsional diperlukan dalam menyusun BAP dan naskah perundang-undangan. Oleh karena itu, cara belajar di atas perlu dikemukakan di sini.

Jika kita lihat KUBI, konsepsi itu adalah rancangan atau pengertian. Jadi, belajar konsepsional sama dengan belajar membuat suatu pengertian atau belajar merancang apa yang telah ada dalam pikiran kita. Hasil dari konsepsi kita tentu saja harus diteliti ulang. Oleh karena itu, seoarang ahli hukum harus selalu berlatih meneliti. 
Penelitian di sini gunanya untuk menkaji konsepsi yang telah kita buat. Apa konsepsinya sudah betul atau masih ada kekurangannya. Pada akhirnya, hasil konsepsi kita dituangkan dalam bentuk tulisan. Rancangan atau konsepsi yang kita buat harus disusun secara baik atau terorganisasi, dengan memakai bahasa ilmiah.

Berdasarkan hal tersebut, dalam praktiknya, cara belajar demikian dapat diterapkan dalam pengelompokan yang diperluas. Pengelompokan yang diperluas sering dilakukan oleh ahli perancangan perundang-undangan, yang pada akhirnya akan menjadi undangundang. Ciri kalimat yang menunjukkan pengelompokkan yang diperluas dapat terlihat dalam konteks kalimat itu sendiri.

Contoh:

(1) Jual beli merupakan bagian dari hukum dagang dan bagian yang tidak terpisahkan dari hukum perdata.

(2) Apabila suatu negara telah menjadi angota $P B B$, maka bangsa dari negara tersebut disebut bangsa yang beradab.

(3) Indonesia adalah anggota Asean, dan semua anggota Asean adalah anggota $P B B$

(4) Kodya Bandung adalah bagian dari propinsi Jawa Barat dan juga bagian yang tidak terpisahkan dari negara Indonesia.

7. Sebab dan Akibat. 
Sebab dan akibat merupakan masalah yang terdapat dalam kasus-kasus hukum. Oleh karena itu, mengetahui materi sebab dan akibat sangat penting bagi bidang ilmu hukum. Betapapun huku itu dapat menyelesaikan masalah yang sering terjadi tetapi, walaupun demikian, belum ada batas-batasnya. Hal ini dapat kita lihat dari pernyataan yang menyatakan bahwa segala sesuatu yang terjadi di dunia ini harus tunduk pada hukum sebab akibat. Dengan demikian, seorang ahli hukum, dalam mencari kebenaran, harus meneliti dulu sebab dan akibatnya.

Dalam mencari kebenaran, alat bukti dan hal-hal lain yang mendukungnya harus diteliti secara cermat, agar pembuktian itu dapat diterima kebenarannya, kita semua tahu bahwa dalam kehidupan ini ada yang bersifat subjektif dan ada pula pendapat objektif. Pendapat yang subjektif terbentuk melalui pancaindera, sehingga menghasilkan kebenaran yang subjektif. Pendapat yang objektif terbentuk melalui akal sehat dan disesuaikan dengan objek atau gejala yang ada dalam masyarakat. Jadi, dalam bidang ilmu hukum, untuk mencari kebenaran itu harus memakai pendapat yang objektif, karena kebenarannya itu harus sesuai dengan fakta yang ada. Hukum tidak boleh direkayasa. Jika hukum sudah direkayasa, maka kebenaran hukum tidak akan pernah ada. 


\section{Contoh :}

Saya rasa ............ ( pendapat subjektif)

Saya pikir ........... ( Pendapat objektif )

Saya kira ............. ( menyatakan keragu-raguan)

Pada hakekatnya, ketiga contoh di atas pemakaiannya baku dalam bahasa Indonesia. Akan tetapi, untuk mendapat kepastian hukum kata saya pikir lebih tepat.. Biasanya, yang menggunakan saya rsa itu adalah sastrawan. Akan tetapi, dalam percakapan sehari-hari kata saya rasa juga sering terdengar. Begitu kayanya pembendaharaan kata bahasa Indonesia, sehingga suatu pendapatpun bisa kita rasakan. Kata saya kira, menyatakan keragu-raguan, sehingga kata kepastiannya diragukan. Kata seperti ini sebaginya digunakan dalam memprediksi sesuatu.

Dalam hal ini, perlu juga diperhatikan bahwa sesungguhnya hukum itu tidak mau dibohongi atau hukum itu tidak mau dimadu. Dalam hukum harus dinyatakan bahwa apa yang benar itu benar dan yang salah itu salah. Pada intinya jika kita menyusun sesuatu dokumen, BAP, dan lain-lain harus benar dan akurat. Jika bohong maka akan diketahui kesalahannya.

Tiada sebab tanpa akibat, itulah mungkin yang ingin digambarkan penulis wacana ini kepada publik. Wacana ini 
menjelaskan bahwa akar biologis ini akan mempengaruhi suatu perilaku keturunannya.

Sebuah peribahasa Belanda berbunyi "die apel valt nietver van de boom" (buah apel tak jatuh jauh dari pohonnya). Sementara itu, peribahasa Inggris berbunyi "like father, like son" ( begitu bapaknya, begitu pula anaknya). Apakah makna kedua peribahasa ini? Maknanya adalah anak-anak mewarisi sifat-sifat kedua orang tua yang melahirkannya. Celakanya, peribahasa itu sering mengandung konotasi negatif; bapaknya jahat, anaknya setali tiga uang.

Secara kriminologis, timbul pertanyaan klasik, apakah kejahatan mempunyai akar biologis atau dibentuk oleh lingkungan. Menurut dua orang guru besar, Richard J. Herrstein dan james Q. Wilson dari Universitas Harvard (1987), sebab-sebab kejahatan berasal dari suatu kombinasi pengaruh bawaan biologis yang disalurkan oleh lingkungan sosial ke dalam sikap tindak kejahatan. Jadi, kedua faktor itu secara bersama-sama memainkan peran penting dalam menciptakan kejahatan namun, faktor mana yang paling dominan tak dijelaskan kedua pakar tersebut.

Sementara itu, hubungan kejahatan dengan faktor biologis antara lain pernah diungkapkan dalam penelitian terhadap anak kembar, oleh para kriminolog Eropa dan Amerika. Anak kembar hasil 
dari pembuahan inti (gen) yang sama atau kembar identik biasanya menghasilkan persamaan watak. Agak berbeda dengan kembar dari dua sel telur yang dibuahi secara terpisah (kembar fraternal). Kesamaan anak kembar identik lebih besar daripada anak kembar fraternal.

Dari hasil studi anak kembar, sehubungan dengan tingkat kriminalitas lebih dari 1.500 pasang anak kembar diteliti di Amerika Serikat, Skandinavia, Jepang, Jerman Barat, Inggris, dan lainnya. Hasil penelitian di negara tersebut secara kualitatif menghasilkan kesimpulan yang sama. Sebagai contoh, Kriminolog Denmark, Karl O. Christiansen, yang memanfaatkan catatan dan laporan mengenai anak kembar di kepolisian, pengadilan, dan penjara di wilayah tertentu, menyimpulkan: Bila salah seoarang dari anak kembar identik memiliki rekor kejahatan tertentu, ada kemungkinan saudara kembarnya mempunyai rekor kejahatan yang sama. Contoh seperti ini dikemukakan dalam kasus kembar fraternal.

Penelitian ini diperkuat pula oleh karya David Rowe, psikolog dari Universitas Oklahoma. la menggunakan kuesioner dengan responden anak kembar di seluruh SMA di Distrik Ohio. Yang dinyatakan antara lain mengenai kegiatan anak kembar sehari-hari, termasuk kenakalannya, pergaulan dengan kawan-kawannya, dan 
pendapat mengenai saudara kembarnya. Hasilnya, terdapat kesamaan watak anak kembar identik dalam kenakalan dibandingkan dengan kasus kembar fraternal. Anak kembar identik yang sering tampil dalam kegiatan positiif bersama-sama jarang melakukan kejahatan.

Namun, ada studi yang lebih menarik; anak angkat, dalam kaitannya dengan sejarah kriminalitas, dikaitkan dengan orang tua asli atau orangtua angkatnya. Dari studi itu, seperti tercatat di kepolisian, terlihat bahwa riwayat kriminalitas orangtua asli memberikan sumbangan penting bagi anak angkat dalam kemungkinan melanggar hukum. Sebagai contoh dapat diketengahkan hasil penelitian Sornoff Mednick, psikolog dari Universitas Southern California, yang bekerja sama dengan para ahli lainnya di AS dan Demnark.

Mereka menelusuri sampel dari beberapa ribu anak laki-laki yang dilahirkan oleh orangtua asli, yang tidak mempunyai rekor kejahatan, cenderung tak pernah atau jarang melakukan kejahatan.

Disimpulkan, orangtua asli yang sering melakukan tindak pidana menimbulkan besar kemungkinan anaknya mengikuti jejak orangtuanya. Risiko ini diperbesar lagi apabila orangtua angkat juga mempunyai rekor kejahatan dari polisi. Bahkan ditemukan juga, kejahatan yang dilakukan anak lelaki itu tak ada hubungan dengan tahu atau tidak tahunya si anak atas prestasi kriminal orangtua aslinya. 
Penemuan ini membuat banyak ahli sosialogi dan kriminologi mancanegara dewasa ini mengakui keberadaan faktor genetis sebagai penyebab timbulnya kejahatan. Yang mungkin berbeda Cuma soal seberapa besar kontribusi faktor genetis ini pada tindak kejahatan.

Sebagai kriminolog Indonesia, saya tak percaya dengan adanya mata kejahatan yang diturunkan orangtua kepada anaknya. Sangat sulit dipercaya adanya gen kejahatan (crime genes). Kendati demikian, tampaknya terdapat atribut besar, yang dalam tindak tertentu mempunyai akar biologis dan mempengaruhi sikap dan tindak kejahatan.

Yang saya maksud adalah faktor kecerdasan dan temperamen seoarang anak yang banyak dipengaruhi orangtuanya. Suatu survey yang canggih, yang belum lama ini dilaksanakan dan di sponsori lembaga/Akademi IImu Pengetahuan Nasional Amerika Serikat (National Academy of Science), memperkuat studi-studi sebelumnya. Hasil survei menunjukkan, pelaku kejahatan yang berkecerdasan tinggi berkemungkinan lebih dapat meloloskan diri dari penangkapan atau tuduhan. Lain halnya dengan mereka yang ber IQ rendah.

Kecenderungan untuk berbuat kejahatan pada paa residivis, kemungkinan besar, lebih merupakan masalah temperamen daripada persoalan kecerdasan. Impuls-impuls yang tak peka terhadap tuntutan 
masyarakat, pemikiran yang kurang jernih dan penuh emosional dalam berhubungan dengan masyarakat lain, dan hasrat untuk berbuat yang menyerempet bahaya adalah karakteristik dari pelanggar hukum yang mepunyai IQ tinggi.

Temperamen pada suatu sikap tertentu dapat dipengaruhi faktor keturunan, memang tidak ada. Ini sesuai dengan fitrah seorang bayi, yakni dilahirkan putih sebersih kapas. (FK: No. 15, tahun IV, 6 November 1995)

Alasan-alasan yang diteliti harus cermat dan aktual merupakan ciri dari adanya sebab akibat adalah karena, sebab, akibat, oleh karena itu, oleh sebab itu, sebabnya, akibatnya, dan lain-lain.

Contoh:

(1) Salah satu penyebab meningkatnya kejahatan adalah pendapatan yang tidak merata.

(2) Devaluasi adalah akibat dari merosotnya nilai uang.

(3) Karena menyembuhkan yang sakit, dokter mendapat uang.

(4) Akibat dari kepercayaan diri rendah, maka pengangguran meningkat.

(5) Tiada sebab tanpa akibat.

(6) Tiada akibat tanpa sebab.

8. Menjelaskan 
Dengan tujuh langkah di atas, sebenarnya seoarang ahli hukum harus sudah dapat menyusuun kalimat yang baik dalam BAP atau juga sudah menjelaskan kasus-kasus yang terjadi dalam bidang hukum. Dalam menjelaskan perlu diingat bahwa segala sesuatu yang berkaitan dengan hukum haruslah tepat dan benar. Kalimat-kalimat yang disusun harus memperhatikan kaidah-kaidah bahasa Indonesia yang baik dan benar. Bahasa hukum merupakan bahasa ilmiah, bahasa ilmiah harus menggunakan bahasa resmi.

Kaidah-kaidah bahasa Indonesia yang diterapkakn dalam bidang hukum akan memudahkan informasi yang disampaikan. Dengan demikian informasi yang disampaikan ahli hukum harus jelas dan benar. .Sudah pasti, tanda baca sangat mempengaruhi imakna kalimat yang diinformasikan. Jika tidak memperhatikan tanda baca (dalam bahasa tulis) atau inotasi (dalamm bahasa lisan), maka kemungkinan besar bahasa yang digunakan mempunyai arti yang lebih dari satu atau bersifat ambigu. Informasi itu harus benar karena kebenaran akan membawa kemajuan. Kemajuan akan membuat orang hidaup lebih baik. Jika informasi bohong, pelaksanaannya pun menjadi salah dan kemajuan tidak akan tercapai. Jadi, jika informasinya tidak benar atau bohong, tidak akan membawa kemajuan dan kehidupan pasti akan mundur. 
Selain tanda baca, kata tugas juga akan mempengaruhi kebenaran atau kesalahan suatu pengertian. Kata tugas juga membuat suatu kalimat menjadi ambigu. Seorang ahli hukum harus benar-benar cermat dalam membuat sebuah kalimat agar tidakk terjadi kesalah pahaman.

Contoh:

(1) Orang itu dibunuh adiknya.

(2) Istrinya yang ada di Bandung sakit.

Jika diucapkan secara lisan, kalimat pertama dapat dipahami artinya, karena menggunakan intonasi. Akan tetapi, secara tulisan kalimat tersebut dapat mengandung beberapa pengertian, yaitu dibunuh oleh adiknya sendiri atau adiknya yang dibunuh. Begitu juga dengan kalimat (2). Kalimat tersebut mempunyai dua pengertian, yaitu istrinya itu tinggal di Bandung atau istrinya itu lebih dari satu, yang tinggal di kota lain.

Dalam bidang hukum, kalimat-kalimat seperti itu seharusnya dihindari karena informasi yang disampaikan tidak akan jelas. Sebaiknya kalimat di atas menjadi:

(1) Orang itu dibunuh oleh adiknya.

(2) Istrinya, yang ada di Bandung, sakit. 
Penambahan kata oleh pada kalimat pertama dan tanda (,) sebagai aposisi pada kalimat kedua memperjelas informasi yang disampaikan. Pengertian objek dalam bahasa belum tentu sama dalam hukum.

Misalnya ada kalimat berbunyi $\quad$ : A memukul B

Sudah jelas dalam bahasa bahwa : $S \quad P \quad O$

A sebagai subjek

A dan B berbeda kedudukannya

B sebagai objek

Akan tetapi, dalam hukum A dan B sama-sama menjadi subjek, yaitu subjek hukum. Tentu saja hukumnya harus selalu melekat disamping kata subjek agar tidak disalahtafsirkan. Sebagai subjek hukum, tentu saja, A dan B mempunyai kedudukan yang sama, yaitu sama-sama mempunyai hak dan kewajiban di dalam hukum. Jadi, jelaslah di sini bahwa betapa pentingnya kemahian berbahasa bagi sarjana hukum. Penguasaan tata bahasa pun sangat perlu, karena tata bahasa itu ilmu untuk menyatakan maksud dengan tepat dan jelas.

Seorang ahli hukum harus teiti membuat kalimat dan harus cakap berbahasa agar dapat dimengerti oleh masyarakat.

Contoh:

(1) ada silogisme yang berbunyi: 
A : Tukang cukur adalah orang yang mencukur orang yang tidak mencukur diri sendiri.

B : Tukang cukur itu tidak mencukur diri sendiri.

Kesimpulan:

C: Jadi, tukunag cukur itu mencukur diri sendiri.

(2) a. Saya mengetahuinya.

b. Saya tidak mengetahuinya

c. Saya pura-pura tidak mengetahuinya.

d. Saya tidak pura-pura mengetahuinya

e. Saya tidak pura-pura tidak mengetahuinya.

Jika dalam silogisme ada salah satu pernyataan tidak benar, maka kesimpulannya pun akan salah (tidak benar). Dalam silogisme di atas, pernyataan pertama (premis mayor) terdapat satu kata yang terlewat, yaitu kata lain sehingga kesimpulannya menjadi salah. Seharusnya, silogisme di atas menjadi:

A. Tukang cukur adalah orang yang mencukur orang lain yang tidak mencukur diri sendiri.

B. Tukang cukur itu tidak mencukur diri sendiri.

C. Jadi, tukang cukur adalah orang yang mencukur orang lain.

Contoh kedua dapat dijelaskan (diartikan) sebagai berikut:

a. tahu 

b. tidak tahu
c. tahu
d. betul-betul tahu
e. betul-betul tidak tahu.

\section{Fungsi Bahasa Indonesia Hukum}

\section{Fungsi Simbolik}

Salah satu pengertian bahasa adalah suatu sistem bunyi atau tulisan yang melambangkan pengertian-pengertian tertentu. Bahasa hukum dapat diartikan sebagai bahasa yang digunakan di bidang hukum yang melambangkan sistem bunyi atau tulisan mengenai pengertian-pengertian hukum. Jadi bahasa hukum baik lisan maupun tulisan harus dapat mengkomunikasikan hukum. Patut disadari bahwa mengkomunikasikan hukum itu tidak mudah, pekerjaan untuk menuangkan atau menyusun pikiran-pikiran atau ide-ide hukum kedalam suatu peraturan perundang-undangan adalah pekerjaan yang sulit, ahli bahasa sendiripun belum tentu mampu melukiskan aturanaturan hukum kedalam suatu undang-undang sesuai dengan kesadaran hukum masyarakat itu sendiri. Demikian juga sebaliknya, orang-orang yang peka terhadap rasa keadilan dan mepunyai motivasi kuat untuk menegakkan hukum, akan tetapi tidak mempunyai dasar yang kuat untuk melukiskannya dengan bahasa atau sama sekali tidak mengerti 
tentang bahasa hukum, mereka juga tidak akan mampu menuangkan ide-idenya atau pikirannya ke dalam suatu peraturan perundangundangan. Hal ini disebabkan karena hukum itu sendiri bersifat abstrak, hukum itu akan tampak apabila ia dapat diperlambangkan, dipersonifikasikan atau diwujudkan dalam bentuk bahasa.

Bahasa hukum sebagai bahasa komunikasi mempunyai bahasa simbolik yakni berfungsi untuk mengkomunikasikan buah pikiran. Fungsi simbolik ini terlihat sangat menonjol di dalam komunikasikomunikasi ilmiah hukum. Didalam komunikasi ilmiah, proses komunikasi itu sendiri harus bebas dari unsur emotif agar pesan-pesan ilmiah yang disampaikan bisa diterima secara reproduktif, artinya identik dengan pesan yang dikirimkan. Akan tetapi sebaliknya hal ini sangat sukar dilaksanakan kecuali informasi yang disampaikan itu menyangkut tentang hal-hal yang tidak pasti, hal inilah yang merupakan salah satu kelemahan bahasa hukum sebagai sarana komunikasi ilmiah sebagaimana menurut John Kemeny (1959), bahasa mempunyai kecenderungan emosional.

Fungsi simbolik bahasa hukum memungkinkan kita untuk memikirkan segala sesuatu yang berkaitan dengan hukum, karena bahasa memberikan kemampuan berfikir secara teratur dan sistematis. Transpormasi objek faktual menajdi simbol hukum yang bersifat 
abstrak diwujudkan melalui perbendaharaan kata-kata. Kata-kata ini dirangkai menjadi kalimat untuk mengungkapkan jalan pikiran atau ekspresi tentang hukum. Manusia hidup dalam dunia pengalaman dan dunia simbolik yang dinyatakan dengan bahasa.

Sebagaimana dikemukakan bahwa fungsi simbolik ini sangat menonjol dalam komunikasi ilmiah, hal ini dapat dipahami karena komunikasi ilmiah mensyaratkan suatu bentuk komunikasi yang berbeda dari bentuk komunikasi yang bersifat estetika. Komunikasi ilmiah bertujuan menyampaikan informasi berupa pengetahuan, agar komunikasi ilmiah ini berjalan dengan baik, bahasa yang harus digunakan harus bebas dari unsur emotif dan harus bersifat reproduktif. Misalnya, apabila seseoarang menyampaikan pesan di bidang hukum seperti; "Anak yang lahir di luar pernikahan yang sah hanya mepunyai hubungan hukum dengan ibu yang melahirkannya". Maka si penerima komunikasi tersebut harus menerima informasi yang sama, hal ini dimaksudkan untuk mencegah apa yang dinamakan dengan kesalahan informasi, yaitu proses komunikasi yang mengakibatkan penyampaian informasi yang tidak sesuai dengan apa yang dimaksud. Suatu informasi yang berbeda akan menghasilkan proses berpikir yang berbeda pula, oleh karena sebab itu proses komunikasi ilmiah harus bersifat jelas dan objektif. 
Dalam bahasa hukum, makna yang terkandung pada kata-kata yang digunakan untuk mengungkapkan secara tersurat aturan-aturan hukum bertujuan untuk mencegah timbulnya pemberian makna yang lain, oleh sebab itu dalam komunikasi ilmiah hukum kita sering menemukan definisi kata-kata yang digunakan, misalnya apabila seoarang ahli hukum mengemukakan pendapatnya melalui komunikasi ilmiah dengan mempergunakan kata-kata seperti "penalaran hukum",

"penegakkan hukum", pembentukan hukum dan sebagainya, terlebih dahulu dia menjelaskan apa yang dimaksud dengan kata-kata tersebut. Hal seperti ini memang harus dilakukan untuk mencegah agar sipenerima komunikasi tidak memberi makna lain yang berbeda dari pengertian yang dimaksudkannya. Apabila diamati dengan berbagai komunikasi ilmiah di bidang hukum, semuanya merupakan pernyataanpernyataan tentang hukum. Pernyataan itu melambangkan suatu pengetahuan yang ingin dikomunikasikan kepada orang lain tersebut atau sipenerima komunikasi dapat memahami makna dari hukum yang dikomunikasikan. Fungsi simbolik selanjutnya dari bahasa Hukum dapat berupa bahasa yang mencerminkan bahasa isyarat. Ini merupakan salah satu keistimewaan dari bahasa Hukum, misalnya simbol yang dipergunakan dalam aturan berlalulintas. 
Contoh:

a.<smiles>O=C1CCC2CCC1CC2</smiles>

b.

C.

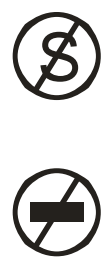

artinya dilarang parkir

artinya dilarang berhenti

artinya dilarang masuk, dan lain-lain.

Lambang-lambang tersebut di atas, bukan merupakan bahasa tulisan dan bukan merupakan bahasa lisan, mempunyai fungsi simbolik sebagai ungkapan-ungkapan perasaan dari pembuat undang-undang atau penegak hukum untuk menjaga ketertiban masyarakat.

\section{Fungsi Emotif}

Dalam dunia pendidikan tinggi, bahasa merupakan salah satu kunci pokok kegiatan proses belajar mengajar. Bahasa dapat mendorong kemajuan berfikir individu dan masyarakat, melalui bahasa dapat ditumbuhkan kemampuan berkomunikasi dan berfikir secara produktif. Dalam dunia pendidikan hokum usaha-usaha yang dilakukan untuk mempelajari hukum dapat berhasil sesuai dengan apa yang diinginkan, apabila dalam pelaksanaannya digunakan bahasa Hukum dengan baik. Hukum apapun yang dipelajari hasilnya sangat ditentukan oleh penguasaan bahasa Hukum yang digunakan dalam proses belajar mengajar tersebut. 
Dalam kenyataannya, Bahasa Indonesia sebagai bahasa Negara telah menjalankan fungsinya sebagai bahasa nasional, bahasa resmi, bahasa pengantar dalam dunia pendidikan, bahasa ilmu dan kebudayaan nasional dan juga sebagai bahasa pergaulan. Akan tetapi bahasa Indonesia sebagai bahasa Hukum masih banyak peranannya yang dilakukan oleh bahasa lain, baik bahasa daerah maupun bahasa asing, hal ini merupakan salah satu kekurangan dari bahasa Hukum sebab sebagai salah satu sarana komunikasi hukum, semestinya raga atau gaya bahasa yang digunakan harus bersifat otoritatif. Artinya berusaha untuk memaksa dengan menggunakan bahasa sebagai sarana komunikasinya dan dilakukan secara rasional. Gustav Radbruch (1979) menyatakan bahwa karakteristik Bahasa Hukum atau peraturan perundangan: bebas emosi, tanpa perasaan, datar dan kering, kesemuanya ditujukan untuk kepastian dan menghindari dwimakna.

Bahasa hukum sebagai sarana komunikasi ilmiah hukum harus bersifat jelas dan objektif serta harus terbebas dari unsurr-unsur emotif. Adanya unsur emotif dalam komunikasi ilmiah hukum, akan menjadikan komunikasi tersebut kurang sempurna, bahkan hukum yang dikomunikasikan biasa saja, kurang berfungsi sesuai dengan tujuan hukum itu sendiri. Hal ini karena aturan-aturan hukum itu tersebut 
dianggap kurang memenuhi rasa keadilan, apabila hukum itu diterapkan secara empiris. Jadi dalam hal pembentukan hukum baik yang menyangkut dengan perancangan perumusan hukum maupun yang menyangkut penerapan hukum, harus disusun sedemikian rupa sehingga memperlihatkan aturan-aturan yang disusun dengan gaya bahasa yang datar, kering, bebas dari emosi. Disinilah terletak perbedaan antara komunikasi ilmiah hukum dengan komunikasi lain, seperti komunikasi yang digunakan dalam bacaan ilmuah populer atau yang digunakan media massa.

Komunikasi yang biasa digunakan dalam bacaan ilmiah popular dapat dibagi menjadi tiga kategori :

a. Komunikasi atau bacaan dalam bentuk diskriptif.

Yaitu hanya membeberkan sesuatu pengetahuan sebagai sekumpulan fakta dengan tujuan untuk meningkatkan pengetahuan pembaca. Biasanya komunikasi dalam bentuk ini menceritakan fakta sebagaimana adanya atau penemuan di bidang keilmuan tertentu.

b. Komunikasi atau bacaan dalam bentuk diskriptif analisis.

Yaitu hanya menjelaskan tentang berbagai masalah yang menyangkut dengan hasil analisis dari suatu fenomena atau 
penemuan terhadap sesuatu pengetahuan atau fakta yang terjadi di dalam masyarakat.

c. Komunikasi atau bacaan diskriptif verifikasi

Yaitu hanya menguraikan secara verivikasi tentang suatu fenomena atau fakta yang ada di dalam masyarakat.

Ketiga bentuk komunikasi tersebut di atas, tidak bias terlepas dari unsur emotif karena memang ditujukan untuk membangkitkan minat atau opini masyarakat agar tertarik untuk mengetahui apa yang diuraikan di dalam komunikasi atau tulisan tersebut. Misalnya, dapat kita lihat dalam kalimat berikut : “ah...saya sebenarnya sangat tidak suka dengan gossip, tapi bagi sebagian teman sejawat saya atau kalangan

tertentu gossip merupakan sarapan pagi yang harus dihidangkan setiap pagi tanpa mempedulikan ini dan itu dan tanpa mempersoalkan..." Contoh ini merupakan salah satu bentuk kalimat yang mengandung unsur emotif, biasa digunakan sebagai komunikasi untuk mengungkapkan perasaan emosional (marah, dongkol, kecewa, sindiran) dari pemberi pesan, untuk mempengaruhi si penerima.

Bahasa hukum sebagai bahasa ilmiah hukum harus bebas dari unsur-unsur yang bersifat emotif, sebab bahasa Hukum merupakan bahasa yang mempunyai cirri khusus sebagai bahasa ilmiah. Bahasa 
Hukum harus mampu mengkomunikasikan secara ilmiah semua aspek yang berhubungan dengan hukum agar komunikasi yang dilakukan dapat diterima, dimengerti dan dipahami dengan baik oleh si penerima sebagai sasaran komunikasi.

\section{Fungsi Afektif}

Bahasa sebagai alat komunikasi, pada hakikatnya mencakup tiga unsur pokok. Unsur pertama menyangkut dengan penyampaikan pesan yang berkonotasi perasaan atau unsur emotif. Kedua sebagai komunikasi untuk menyampaikan pikiran atau komunikasi simbolik. Ketiga sebagai komunikasi yang berkonotasi sikap yaitu unsur efektif. Perkembangan bahasa pada hakikatnya merupakan pertumbuhan dari ketiga fungsi tersebut. Fungsi simbolik menyangkut dengan aspek ilmiah, sedangkan fungsi emotif dan afektif berkaitan dengan seni, secara teoritis dapat dikatakan bahwa kemajuan di bidang seni berhubungan dengan perkembangan bahsa dalam fungsi emotif dan fungsi afektifnya. Akan tetapi pembagian fungsi tersebut di atas bukan merupakan pembagian yang bersifat mutlak, pembagiannya hanya bersifat katagoris dengan tidak memisahkan fungsi yang satu dengan yang lain secara tegas.

Fungsi afektif dalam Bahasa hukum berkaitan erat dengan sikap, fungsi ini diharapkan supaya norma-norma hukum yang 
dikomunikasikan melalui bahasa hukum,mampu mengubah dan mengembangkan kepribadian agar mentaati hukum, meningkatkan kesadaran hukum serta bersikap tegas sesuai dengan aturan-aturan hukum. Hal ini juga berarti bahwa dengan mempelajari bahasa hukum, mahasiswa hukum telah berusaha untuk mengembangkan kepribadiannya yang baik harus dilakukan dengan jujur, sehingga hasil yang akan dicapai merupakan kepribadian yang matang dan stabil, sebab hanya melalui kepribadian yang matang dan stabil orang dapat berbuat dan bertindak sesuai dengan aturan-aturan hukum. Sejalan dengan itu, mempelajari bahasa Hukum berarti bertujuan untuk mengembangkan semua potensi setiap mahasiswa hukum untuk memahami hukum, sehingga mampu bersikap sesuai dengan normanorma yang ditetapkan dalam hukum.

Pada dasarnya fungsi afektif yang tergambar dalam bahasa Hukum itu sangat menonjol untuk meningkatkan dan mengembangkan budaya hukum, budaya hukum itu sendiri merupakan suatu karakteristik yang hidup dan dipatuhi oleh masyarakat. Budaya hukum suatu daerah yang dianut oleh masyarakat hukum adat setempat merupakan pedoman dan tuntunan hidup bagi masyarakat yang bersangkutan. Contoh; Bahasa hukum yang diungkapkan dengan katakata "gono-gini", hal ini berarti bahwa baik mengenai pembagian 
maupun yang menyangkut dengan gono-gini tersebut dilakukan atau dilaksanakan menurut adat setempat. Jadi dalam hal ini bahasa Hukum merupakan salah satu sarana yang dapat digunakan untuk mempengaruhi sikap masyarakat terhadap hukum.

\section{SIMPULAN DAN SARAN}

\section{A. SIMPULAN}

1. Bahasa memegang peranan yang sngat penting dalam kehidupan sehar-hari karena tampa adanya bahasa komunikasi tak akan terjadi, oleh karena itu, untuk mencapai komunikasi yang terstruktur dan sitematis dipelajarilah bahasa. Sejarah membuktikan bahwa bahasa Indonesia terutama bahasa undangundang berasal dari produk orang Belanda (hasil jajahan bangsa Belanda). Pakar hukum Indonesia pun banyak belajar ke negeri Belanda kerena hukum Indonesia mengacu pada hukum Belanda. Para pakar hukum Indonesia menerjemahkan langsung pengetahuan dari bahasa Belanda ke dalam bahasa Indonesia tanpa mengindahkan struktur bahasa Indonesia itu sendiri. Ini dapat dilihat dari kebenaranya kata di mana, yang mana, dari mana, hal mana. Sebenarnya hal tersebut tidak perlu terjadi karena kata di mana, yang mana, dari mana, hal mana itu 
merupakan kata tanya, di dalam kalimat berita atau kalimat pernyataan dalam bahasa Indonesia tidak ada tempat untuk menggunakan kata tanya. Di samping itu juga penelitian membuktikan bahwa kaum cendikiawan Indonesia sampai saat ini masih belum fasih berbahasa Indonesia secara terstruktur. Padahal jika kita lihat bahasa Indonesia yang menggunakan Ejaan Yang Disempurnakan ( EYD) sudah empat puluh delapan tahun diresmikan dan bahasa Indonesia diikrarkan sudah 86 tahun yang lalu, sudah terlihat perkembangannya tetapi keajegannya kurang diperhatikan oleh orang Indonesia sendiri. Ini perlu segera dibenahi karena tiap tahun orang asing yang belajar bahasa Indonesia (di Fakultas Sastra) terus berdatangan. Jangan sampai pada akhirnya orang Indonesia belajar bahasa Indonesia di negara asing.

2. Bahasa hukum bukanlah bahasa yang berdiri sendiri, melainkan murupakan bahasa Indonesia yang khusus diterapkan untuk bidang hukum. Hal ini berarti bahwa bahasa hukum tidak boleh meninggalkan kaidah-kaidah yang berlaku dalam bahasa Indonesia, baik mengenai susunan kalimat, asal usul kata, arti kata maupun aturan-aturan lain yang berlaku dalam bahasa Indonesia. Pola pikir yang konsepsional adalah suatu teori praktis 
dalam membuat suatu karangan ilmiah, tentunya bahasa hukum juga mempunyai ciri khas sesuai dengan karakter yang terdapat dalam ilmu hukum itu tersendiri, dalam beberapa hal penggunaan bahasa hukum ini berbeda dengan bahasa Indonesia pada umumnya, misalnya penggunaan bahasa di dalam akta dan putusan pengadilan, namun perbedaan tersebut hanya bersifat kasuistis sesuai dengan apa yang dimaksudkan di dalam akta atau putusan pengadilan tersebut, termasuk pemakaian bahasa dalam keilmuan lainnya, hal ini dapat dilihat dari penggunaan kata yang hanya berlaku untuk keilmuan tertentu saja yang biasa kita sebut bahasa fungsional atau bahasa profesi.

3. Ragam bahasa Indonesia hukum dilihat dari segi linguistik adalah meta bahasa yaitu merupakan ragam hasil kajian atau produk pemikiran manusia yang tidak terbatas kepada satu bahasa saja, tetapi juga melibatkan keilmuan lain. Dipandang dari bahasa hukum maka bahasa Indonesia hukum adalah sarana utama untuk menjalankan profesinya, sehingga bahasa profesi mempunyai ciri yang berbeda dari ragam bahasa umum.

\section{B. SARAN}


Sehubungan dengan bahasa itu mempunyai peran yang sangat penting dalam kehidupan manusia sehari-hari, maka kami sarankan bahwa semua yang berkencimpung dalam menggali suatu keilmuan khususnya dalam ilmu hukum, agar tidak henti-hentinya belajar bahasa Indonesia hukum, dikarenakan pola berpikir secara konsepsional dan sistematis diperlukan belajar secara terus menerus. Bahasa bersifat dinamis (tidak statis), artinya bahasa bisa berubahubah sesuai dengan kebutuhan dalam kehidupan manusia, beratusratus kata serapan yang berasal dari bahasa asing adalah merupakan contoh sifat bahasa yang dinamis, untuk dapat dijadikan bahasa Indonesia yang baku, termasuk menyaringan bahasa dari luar bahasa Indonesia harus melalui proses penyerapan sesuai dengan kaidah (standarisasi) yang telah ditetapkan oleh Lembaga Pembinaan dan Pengembangan Bahasa Indonesia (LPPBI) di Jakarta.

\section{DAFTAR PUSTAKA}

Antieau, Chester, 1993, Contituentional Contruction, Oceana Publications, Inc.

B. Johan Nasution, 1998, Bahasa Indonesia Hukum, Bandung, PT. Citra Aditya Bakti. 
Badan Pembinaan Hukum Nasional (BPHN), 1974, Bahasa dan Hukum, Medan, CV. Binacipta.

Depdikbud, 1975-1985, Ejaan Bahasa Indonesia Yang disempurnakan (EYD), Bandung, Depdikbud.

Departemen Pendidikan dan Kebudayaan, 1979, Kamus Umum Bahasa Indonesia, Jakarta, Balai Pustaka.

Zaenal Ariffin, 1995, Cermat Berbahasa Indonesia Untuk Perguruan Tinggi, Jakarta, CV. Akademika Pressindo.

Hilman Hadikusmana, 1984, Bahasa Hukum Indonesia, Bandung, CV. Alumni.

JS. Badudu, 1995, Inilah Bahasa Indonesia yang Benar, Jakarta, PT Gramedia Pustaka Utama.

Soelaeman B. Adiwidjaya, 2003, Bahasa Indonesia Hukum, Bandung, CV. Pustaka. 